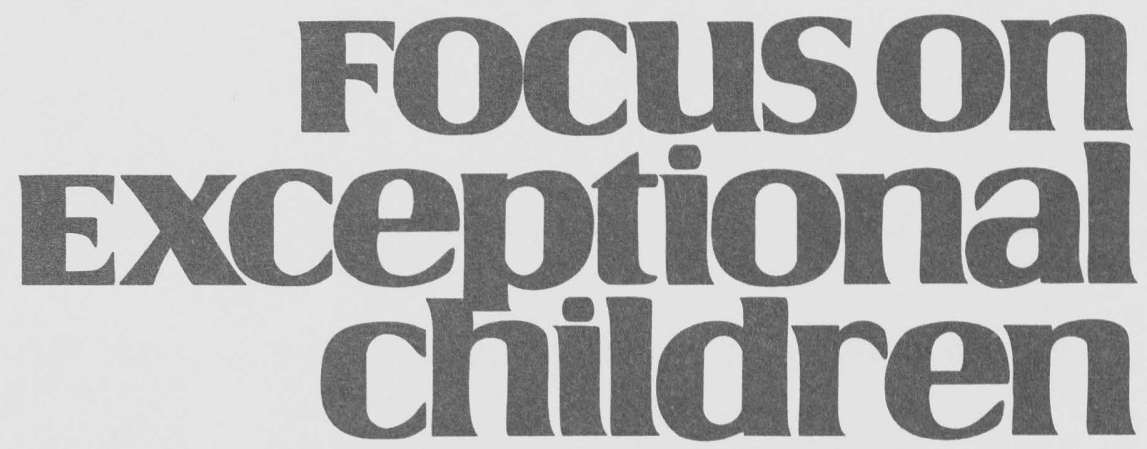

\title{
Promoting Dignity: Taking the Destructive D's out of Behavior Disorders
}

\author{
Patricia A. Gallagher
}

Each year since the passage of PL $94-142$ in 1975 , about $1 \%$ of the school-age population has been identified as seriously emotionally disturbed and has received special education and related services. Caring, knowledgeable adults who work with these children have had positive influences on their lives. At the same time, however, some adults unknowingly have done a disservice to them.

Have the rules and regulations of PL 94-142 - which require diagnostic, educational, and support services to children in stress-been implemented by professionals who inadvertently have contributed to a picture of discouragement to the children and their families, as well as school and community members? Have we missed opportunities to develop educational programs that emphasize greatness and show how to attain it? Troubled children rarely are afforded the opportunity to view themselves as valuable and worthy. For a long time they have been the recipients of special services, and "we have inadvertently given them the message that they are in an inferior position" (Curwin, 1993, p. 65). Given this backdrop, it is time we concentrate on positive, successful practices and develop new ones that emphasize courage and dignity, thereby rejecting the destructive "D's."

This article describes some common discouraging practices that have been used since the passage of PL 94-142 by teachers, psychologists, administrators, university educators, therapists, and related service personnel, many of whom have otherwise dedicated their careers to supporting and guiding troubled youth. These accounts will be followed by descriptions of ways to modify discouraging practices and increase practices that emphasize the creation of safe classroom climates that are permeated with care and include hope, a precursor to optimism and the engine of change.

\section{THE DESTRUCTIVE “D'S”}

Current school practices that fail to recognize or emphasize the dignity of troubled children include scornful labels, negative multiassessment practices, IEPs that do not include students' strengths, punitive management programs, disparaging remarks to children, and behavioral descriptions that accentuate weaknesses.

Patricia A. Gallagher is affiliated with the University of Kansas Medical Center. 


\section{Destructive Labels}

Preceding the preassessment and multiassessment processes that culminate in a troubled youth's enrollment in special education are the " $\mathrm{D}$ " words that adults use to describe children at risk. The words dysfunctional, difficult, deviant, disordered, disturbed, difficult, disappointing, delinquent, dropout, disruptive, and disorganized are demeaning and contemptuous. These terms place blame on the children for their behaviors. The children, not the behaviors, receive the condemnation. Thus, the children become victims.

Adults who do not separate the actions from the individual fail to recognize the heavy burdens many children carry. Some of these adults react with anger and deliver punishment or push the children aside. Often overlooked by those who blame the children are the deplorable physical, emotional, mental conditions in which some children live or the methods they have come to rely on to avoid punishment, receive at-

\section{Focuson
Exceptional
childiren}

ISSN 0015-511X

FOCUS ON EXCEPTIONAL CHILDREN (USPS 203-360) is published monthly except June, July, and August as a service to teachers, special educators, curriculum specialists, administrators, and those concerned with the special education of exceptional children. This publication is annotated and indexed by the ERIC Clearinghouse on Handicapped and Gifted Children for publication in the monthly Current Index to Journals in Education (CIJE) and the quarterly index, Exceptional Children Education Resources (ECER). The full text of Focus on Exceptional Children is also available in the electronic versions of the Education Index. It is also available in microfilm from Xerox University Microfilms, Ann Arbor, MI. Subscription rates: Individual, $\$ 30$ per year; institutions, \$40 per year. Copyright (C) 1997, Love Publishing Company. All rights reserved. Reproduction in whole or part without written permission is prohibited. Printed in the United States of America. Periodicals postage is paid at Denver, Colorado. POSTMASTER: Send address changes to:

$$
\begin{gathered}
\text { Love Publishing Company } \\
\text { Executive and Editorial Office } \\
\text { P.O. Box } 22353 \\
\text { Denver, Colorado } 80222 \\
\text { Telephone (303) } 757-2579
\end{gathered}
$$

Edward L. Meyen

University of Kansas

Richard J. Whelan

University of Kansas Medical Center tention, achieve competence, assert power, or gain rewards. Brendtro, Brokenleg and Van Bockern (1990) have identified ecological hazards, "destructive relationships, climates of futility, learned irresponsibility, and loss of purpose" (p. 6) that troubled youth experience. These authors ask that adults look at those hazards instead of looking at the "D" labels.

Labels can be disabling for troubled students who have to fight against their stigma and the fear and prejudice that accompany labels. Although the special education field has designed an elaborate system for attaching labels, it has no system for removing labels. Do these early labels that emphasize students' deficiencies result in special education programs that reduce optimism for change and the dignity of troubled youth?

\section{Negative Multiassessment Practices}

During the multiassessment process, caring adults often commit a subtle form of punishment. If the evaluation results meet the federal definition of seriously emotionally disturbed and a given state's, as well as local education agency's, the label "disordered" or "disturbed" is assigned to the student. This label indicates that a student's behavior diverges from the norm and substantiates the concerns that adults had for the student to begin with. By using a " $\mathrm{D}$ " label to admit the student to special services, we emphasize deviance. Thus, a subtle but profound message of unworthiness is conveyed to troubled students as soon as they enter special education.

Culprits that lead to the label seriously emotionally disturbed include some rating scales used widely in the assessment process. These consist of a list of behaviors and the frequency of occurrence. Observers record "never" to "frequently"; or "does not exhibit the behavior" to "once or several times in an hour." Some rating scales contain a preponderance of negative behaviors. Example items are "gets angry when given a directive," "lies when confronted with evidence regarding stolen items," "is cruel to animals," "jumps from task to task," "refers to self as dumb, stupid, or incapable," "throws tantrums."

Based on rating scales such as these, when data from the evaluation process are discussed at an IEP planning meeting, the troubled youth's weaknesses receive considerable attention while strengths and special interests are considered minimally. As a result, an evaluation that catalogues deficits may serve to confirm students' beliefs about their unworthiness. "These kids don't think they can do anything positive, but they know what they can do negative" (V. Rezmerski, personal communication, April 1991). 


\section{Weakness-Focused Individualized Education Plan}

Students who exhibit a sufficient number of problem behaviors and are labeled with discouraging words such as "disordered" and "disturbed" become eligible for special education. This leads to the planning of an individualized education program (IEP), a plan that uses information from the generally demeaning characterization of the student.

As a university professor, my concern for what teachers had shared with me regarding the contents of IEPs prompted me to initiate a survey. I asked two groups of career teachers of students identified in their state as "behavior disordered" to review their students' IEPs and determine the number of goals and the categories of these goals. The 34 teachers who responded to the survey were attending one of two graduate courses. Ten were from a large metropolitan area, and 24 from smaller cities and rural areas in the Midwest. All had general education teaching certificates. Thirty-three had full certification in behavior disorders and at least 5 years' teaching experience in this area. All had chosen careers to teach troubled youth.

IEP goals for 285 students ranging in age from 3 to 19 years were identified. The largest group consisted of $223 \mathrm{stu}-$ dents, ages 10 to 17 years. The teachers were asked to classify the goals into one of three groups: (a) Remediate a weakness. Example: Student is below expected performance level, and the goal is designed to bring the student's skills to that level; (b) Build a skill. Example: Student has prerequisite skills and is ready to learn a new skill at his/her expected level of performance; (c) Enhance a skill. Example: Student has a special talent or skill that will be enhanced or used in his or her school program, such as skilled at drawing cartoons; enjoys catch-and-release fishing; repairs bicycles; makes others laugh; memorizes Michael Jordan's scoring records; styles hair creatively.

The 285 IEPs yielded a total of 1,156 goals, an average of four goals per student. Of these, 755 goals fell in the "remediate a weakness" category; 328 goals were in the "build a skill" category, and the remaining 73 belonged to the "enhance a skill" category. Thus, on average, a student with four goals would be directed to remediate 2.65 weaknesses and to learn 1.15 new skills commensurate with the expected level of performance. One in four students would be involved in activities to enhance an existing skill.

It is reasonable to assume that the multidisciplinary teams associated with these 285 students had focused on the students' problems, which then distracted them from recognizing areas of strengths. Undeniably, troubled youth carry heavy burdens and often choose inappropriate behaviors to manage them, thereby causing conflicts with others. In looking at these IEP goals, however, where is the optimism and belief in greatness for the 285 students? On a more discouraging and distressing note, do these IEPs with marginal considerations for students' interests and skills differ from the thousands of others that have been written?

\section{Punitive Management Programs}

In the report, At the Schoolhouse Door, Knitzer, Steinberg, and Fleisch (1990) made a frightening observation regarding classroom control. These authors found that teachers emphasized authoritarian behavior management systems to the exclusion of programs involving students in cognitive management techniques. There seemed to be a preoccupation with a curriculum of control, using the teacher's power to coerce or intimidate students into compliant behavior.

Why would caring teachers implement such programs? Could it be that university programs tend to prepare teachers to develop curricula of control? Or were the teachers initially prepared to implement management programs that emphasize internal locus of control but had become so worn down by the day-to-day stressors in working with troubled youth that they used their power of control? Nichols $(1992$, p. 8) suggested 12 reasons for using such management systems; among them: (a) control is a teacher's duty; (b) control works; (c) society and administrators expect classroom control; and (d) prescribed discipline programs are easily followed by teachers.

In the 1960s, when behavior management techniques based on operant conditioning research began to influence management programs for troubled youth, proper application of the techniques was widely misunderstood. As a result, some programs evolved that focused on deceleration of negative behavior using punishing consequences. Fortunately, many of these misunderstandings gave way to programs that rewarded appropriate behaviors and taught incompatible and new behaviors to replace negative behaviors, advancing in the 1980s to techniques that focused on cognitive self-management techniques.

Despite these positive developments in the area of behavior management, descriptions of response cost management systems have emerged during the past 8 years and appear to me as déjà vu of the curriculum of control of the 1960s. A most flagrant example is one used in a special education classroom for intermediate-aged troubled youth. When the students begin their day, they receive 100 points. As the day progresses, students lose points for exhibiting any one of 27 behaviors listed on a chart on the wall by the classroom door. These be- 
haviors include "verbal abuse," "laziness," "provoking others," "dumb stunts," "out-of-seat," "clowning," and "talkouts." Points are not given for appropriate behaviors. Students who have 450 points at the end of the week can enjoy a special activity. This response cost system is a glaring example of a curriculum of control.

Another negative management system is being used in a general education second-grade classroom that includes special education students. A huge drawing of a doghouse is posted on a classroom wall, and children are sent to the doghouse for misbehaviors, which are capriciously identified by the teacher; the students do not know in advance what behaviors will result in offenses. The student sent to the doghouse sits on a chair in front of the doghouse for a time determined indiscriminately by the teacher. In addition, when the student leaves the doghouse, he or she wears a doghouse tag for the remainder of the school day.

Why would teachers humiliate and devalue children in this way? Clearly, these examples of adult intervention profile the four ecological hazards- - "destructive relationships, climates of futility, learned irresponsibility, and loss of purpose" - discussed by Brendtro et al. (1990, p. 6). The two management systems are examples of punishment, negating caring relationship between teachers and their students. Further, these are not examples of discipline programs. Discipline is a process of teaching. Instead, the programs are examples of courage denied! They intensify the students' inadequacies and are totally lacking in hope or optimism.

\section{Disparaging Remarks}

During the last 4 years I have asked graduate students, teachers who hold general education teaching certificates and are enrolled in courses that prepare them as teachers of troubled youth, to list for a week the negative comments they hear other teachers direct to general and special education students. Originally, this was a casual request to my students, but when they shared their observations, an appalling list of statements emerged. Thinking that this was an aberrant collection, I asked teachers in subsequent courses to do the same activity. The results were similar.

Were the teachers who made these debilitating statements "stressed out?" Overwhelmed with demands? Feeling helpless, frightened, or out of control? Were these isolated statements, or were they part of a series of verbal abuses? What do students internalize when they hear from their teacher, "I can't wait until you are 16 so you'll drop out"; "You never shut your mouth"; "Why should I trust you this time; you always lie?";
"It's not my fault you're special ed and can't understand anything; I didn't want you in my class anyway"; "You have an IQ of 1"; "It's about time you cleaned up that mess you call a desk"; "I can't understand anything you said; class, can any of you understand anything he said?"; "That answer was really dumb; try thinking for a change!" "You're a born troublemaker." One class of high school students had to write 500 times, "I must keep my big fat mouth shut in science class."

Students who are recipients of belittling statements respond in one of three ways: (a) they may react by using putdowns to the teacher; (b) they may say nothing at the time but strike back later; and (c) they may accept the put-down, believing the remarks are true. How can hope and optimism be conveyed to students when teachers use put-downs-statements that reinforce or predict failure or ridicule a student's behavior?

In addition to these glaring examples of put-downs, an indirect form of attacking a troubled youth's incompetence arises from casual remarks that special education teachers often make to colleagues. For example: "I hope Chris is absent; our class is so different without him"; "Jake was a tornado today; it took 30 minutes to settle him down"; "The kids were climbing the walls this morning"; "Emily is the sickest student I have ever had; she does the strangest things." Statements such as these may arise from a teacher's worry for a student's welfare or from frustrated efforts to teach and reach students, but what images do colleagues in general education develop if they hear these regularly from the special education teacher?

\section{Behavioral Descriptions that Accentuate Student Weaknesses}

A less visible negative practice involves descriptions of students' performances. During years of contact with teachers, I have seen teachers prepare lessons and work diligently to help students achieve. The results of their endeavors are reported accurately but, again, they often convey more struggles and weaknesses than student accomplishments.

To point out this bias in the hope of changing teachers' behavior, I have conducted the following activity with hundred of teachers: Teachers view a short videotape of a teacher interacting with a pupil in a one-on-one arrangement. After the teachers view the tape, they are asked to write a description of what they saw. After the session, I read the descriptions, identify all the adjectives and verbs used, and complete a frequency count of them. I take the highest numbers and write a composite description of the pupil in the videotape, which is shared with the teachers during the next session. 
Examples from two groups of teachers are as follows: Composite 1: "Katilyn is a passive-aggressive student who smiles a lot. She is noncompliant. She does not follow directions and pretends she is not listening. She has poor communication skills. She is frustrating to teach." Composite 2: "Katilyn is attractive and smiles a lot. She can learn and is capable, but she smiles to get out of work. She is manipulative, plays dumb, does not follow directions, refuses to perform, and doesn't communicate. I am very frustrated watching her."

As a part of the exercise, the teachers were asked if these were accurate descriptions of the pupil. After a discussion, the teachers had an opportunity to view the videotape again and were asked to be more accurate, such as doing frequency counts and looking for the pupil's positive behaviors to be included in their descriptions. After a tally of the verbs and adjectives in the second set of descriptions the results were conveyed in a composite description of the pupil, as follows: "Katilyn is a quiet child, who, when she does speak, speaks in a whisper. She had good eye contact and smiled a lot while she worked. She was able to identify 13 words from her stack of cards and used excellent handwriting to write those words on a sheet of paper. She had a successful lesson until the teacher told her it was time to put away the cards and get ready for math. Katilyn would not put away her cards even though the teacher told her 12 times to do so."

Why did the teachers' first descriptions contain more negative and interpretative comments such as "noncompliant?" Many of the teachers responded that, from the introduction in the videotape, they knew she was a "BD student." Were they expecting poor performances from the pupil? Were they pessimists who describe a half-filled glass of water as being half empty?

After a discussion, the teachers became more optimistic and described the glass as half full. The initial descriptions of Katilyn contained accuracies, as did the second description, but the point here is that the choice of words can lead to different beliefs and actions. Those who viewed Katilyn as noncompliant might develop a management system focusing on her negative behaviors, whereas those who described Katilyn as a cooperative, successful student might develop a management system to enhance her strengths. Being positive conveys the belief that something can be done and, therefore, focuses us into forward action.

\section{PROMOTING DIGNITY AND COMPETENCE}

Some of the damaging practices identified in the preceding section should be eliminated, and others should be modified to highlight students' competence. To accomplish this, teachers can select strategies and techniques from the professional literature, convention proceedings, classroom observations, commercial materials, and collegial communications to let troubled youth know they are significant individuals. In addition, suggestions to modify negative practices, as well as descriptions of enhancing and promising practices, are given in the following paragraphs.

\section{Labels: Dignifying Their Meaning}

Kauffman and Pullen (1996) argued against those who would abandon labels on the basis of their being damaging and useless. Instead, they suggested the culprits are the meanings we attach to them. Labels can be useful. They assist us in communicating, advocating and making individuals eligible for services. Recognizing that labels are an inevitable part of discourse, Kauffman and Pullen recommended that we "work more diligently in correcting and humanizing the meanings we attach to labels" (1996, p. 10).

A crucial element in humanizing is caring. The following paragraphs discuss the emerging interest in this topic, including the value of caring in schools, how to communicate caring, and strategies such as gentle teaching and peacebuilding to promote caring.

\section{Caring in Schools}

A special section in an issue of the Phi Delta Kappan journal was devoted to the topic of caring in our schools. The basic thrust of the series of articles was underscored by Joan Lipsitz (1995), who answered the question of why we should care about caring in this way:

\begin{abstract}
Because without caring individual human beings cannot thrive, communities become violent battlegrounds, the American democratic experience must ultimately fail. ... The fact that schools are too frail a reed upon which to rest sole responsibility for fostering the humanity of the next generation does not relieve them of their obligation to play their essential part in the intergenerational drama. (p. 665)
\end{abstract}

Noblit, Rogers, and McCadden (1995) expressed concern that caring relationships - that is, making connections with others-are not on the priority list in school programs. Their research, however, reveals that caring creates greater possibilities for learning because meaningful teacher/student relationships promote students' sense of self-worth and students feel better about themselves and recognize their capabilities; therefore, their academic, as well as interpersonal, learning 
takes on greater meaning. The report, A Nation Prepared: Teachers for the 21st Century (1986) included a statement that relates to the topic of caring:

If this country is to remain true to itself, our children should grow up to be humane and caring people, imbued with a set of values that enables them to use their skills in the service of the highest goals of the larger society. (p. 45)

Those who write about the value of providing caring classrooms suggest that education should devote some of its resources, time, and commitment to this value. They contend that children need to believe they are cared for if the learning of prosocial skills and academic content is to take on meaning in their lives. Caring is a personal and professional attribute that teachers can cultivate.

\section{Communicating Caring}

Students labeled as seriously emotionally disturbed need contact with caring adults who can influence their lives in a significant way. Morse (1996) suggested that teachers who care deeply for children must show this in ways the students recognize. The task is to communicate care so students feel it. An incident from a classroom illustrates the importance of this recommendation.

After a very "trying" day, Matthew said to his teacher, Miss Danek, “. . . but I didn't know you cared.” After school, the teacher lamented that those words "hit hard. I spend evenings and weekends, long hours planning, grading, attending professional meetings, reading professional journals, conferencing with parents, community agencies, and support staff because I care. I' $m$ always looking for ideas I can use to motivate and encourage my students, but Matthew doesn't know this. How many other students don't know I care?" Although this teacher had not read Morse's article, she understood the meaning of his message.

After this reflection, she initiated a systematic program of conveying caring in everyday communications with her students. She was more consistent in greeting and welcoming the students as they entered the classroom. She also made a list of words that conveyed caring and found that the following affected the students the most: responsible, worthy, valuable, brave, courageous, treat, special, thoughtful, and on the edge of greatness. She kept a class list and placed a mark by each name after she conveyed a caring word to the pupil. Although this may seem contrived, Miss Danek said her days were so busy that she wanted to be sure each student received daily caring statements in addition to all the other classroom com- munications. After weeks of this program, she reported that the room's atmosphere was happier. In addition, students were conferring the complimentary words on each other. Thus, an unintended but welcomed side benefit was the students' modeling the communication of caring to others.

If we were to keep a mental account of saying silently to everyone we encountered in a month, "I care and value you," significant changes in relationships could come about. Teachers could do a shortened version of this when they find themselves overlooking the dignity of youth during times of stress. In addition, they can suggest the mental exercise to others who use disparaging remarks when speaking to children and about children.

\section{Gentle Teaching}

The concept of gentle teaching (McGee \& Menolascino, 1992) includes the belief that caring is a critical variable in the education of children. Gentle teaching is an intervention strategy that rejects behavioral techniques, including contingent recognition through social approval or tangible rewards, and focuses instead on unconditional human valuing and reciprocal relationship techniques for use in classrooms, including those that have children identified as aggressive or self-injurious.

Reciprocal relationships are considered genuine when individuals seek shared contact in interactions, in contrast to one individual controlling the interactions. Human valuing includes the noncontingent expression of social recognition such as pleasurable facial expressions and playful interactions (for example, giving the "thumbs up" and "right on" signs) and assisting warmly (for example, helping in the spirit of friendship).

\section{Peacebuilding}

Programs have been developed that encourage students to be respectful, responsible, and altruistic. PeaceBuilders (1995) recommends laying a foundation in kindergarten through fifth grade that teaches children and their parents a peacebuilding way of life. This is a proactive program that emphasizes learning selective social skills, such as how to reduce insults, accept feedback, engage others in cooperative tasks, and use praise and self-monitoring behavior. A peaceful environment reduces the need for conflict-resolution techniques.

Kindness is Contagious . . Catch It! (1992) is another published program that emphasizes caring. Its activities make children aware of the impact of words and actions, teach human respect, empathy, and kindness, and engage parents and other adults in supporting and caring behaviors. 
Teaching Children to Be Peacemakers (reported in Johnson \& Johnson, 1996) encourages students to change their perspective about conflicts and learn specific mediation and negotiation techniques. Program activities help students identify conflicts as inevitable life events, while recognizing that not all conflicts involve anger and hostility and can be constructive. Conflicts can have positive effects when the students involved are satisfied with the outcome, the relationship is established or strengthened, and the lessons learned can be applied in future disputes.

Although caring teachers and other professionals cannot reshape the entire field of education, they can search for new paradigms and promising practices. In addition, they can shift their perspectives as they continue their work with troubled youth. The previous paragraphs suggest that caring already resides in good teachers but that this valued quality has to be highlighted in the classrooms. All of us associated with the lives of troubled youth must communicate to all community members that children are sacred beings.

\section{Assessment: Discovering Strengths}

Neel and Cessna (1993) suggested that "behavioral intent" is a critical variable to consider in the assessment process:

\begin{abstract}
When students act, even demonstrating behaviors that we view as disordered, they act for a purpose, "Behavioral intent" refers to the purpose sought by the students as inferred from analyzing a series of overt behaviors in various situations. ... "Behavioral intent" ... involves determining the connection between observed behaviors and the outcomes expected by the student. (p. 33)
\end{abstract}

Once the intent is determined, the focus of instruction is on replacing problem behaviors with desirable behaviors that will help the students achieve the desired intent. For example, Jeffery wants to have friends, but his approach has a negative effect on his peers because his conversations consist of the gory details of sensational murders. He hangs around small clusters of students who obviously are ignoring him and grabs jackets and backpacks and throws them in the air. His intent to have friends is disguised by his inappropriate behaviors until it is revealed by careful observations. This recognition provides the teacher with information necessary to teach Jeffery the social skills he needs to gain friends.

\section{Assessing Strengths}

Results of the assessment process, at the very least, should be like a ledger sheet that contains a balance of deficits and as- sets; however, most individuals would prefer a sizable assets column. The "educational system should endeavor to find and develop each individual's strengths, rather than "hammer away' at the individuals' academic weaknesses" (Rogers, 1989 , p. 487). For years, children with behavior problems often have been characterized as having "a sizable "failure pattern' in living instead of a 'success pattern' " (Haring \& Phillips, 1962, p. 1).

In addition to all the "D's" that usually are emphasized, assessment should include standardized tests, rating scales, direct observations, and samples of student work that reveal the students' strengths and special interests. Discussions that evolve from this assessment might include suggestions for applying and integrating the student's strengths into the education plan, thereby acknowledging the student's worthiness.

For example, Sean's work papers typically are covered with detailed drawings of building interiors, which some call "messy." Comments relevant to his work instead could recognize his drawing ability, and the team could explore with Sean his possible interest in learning drafting techniques, studying interior design, or learning about architectural styles. His response also would suggest the possibility of introducing academic content such as math assignments that involve measurements; a topic for a composition; a research project; or as a subject to pursue in a computer search

In addition, and equally important, this approach conveys the message that students with behavior problems are competent. They act for a purpose and need to learn new methods to reach goals and gain rewards. Focusing more on students' strengths ameliorates previous damaging views of the students and allows educational planning to begin with altered perceptions and confidence in the student. Students embarking on a special education remediation plan have a right to hope. The pursuit of strengths and special interests can provide hope: "Students who concentrate on areas in which they excel are more likely to develop self-confidence and selfesteem" (Rogers, 1989, p. 479).

\section{Identifying Strengths}

Teachers can design checklists to use with incoming and current students to identify their interests and special skills. A checklist could contain items such as:

I am really good at doing in school. I am really good at doing at home.

I am really good at doing neighborhood. in my 
- If I had a chance to choose one thing I would like to learn in school, I would choose

What motivates me the most to do well in school is

The instructional equipment I like to use the most is

When I work hard, I want the teacher to

I can do written assignments if I can do them

When I am not in school, I would like to learn about

_ I have a special interest in and would like to

I know how to

Currently, formal assessment ends with a "D" label, confirming students' beliefs about their inadequacies. To turn this around and give students hope and reassurance that success is within their reach, students' special strengths and interests must be included in educational planning. Success builds on success.

\section{Individualized Education Program: Encouraging New Beginnings}

Beginnings are important, so the individualized education program should begin by inviting success. If special education teachers want troubled students to believe teachers are their advocates, they must communicate caring, convey expectations that students will be winners, present academic tasks at students' instructional level, include special interests in the curriculum, acknowledge the students' intent and teach new behaviors to reach it, and select management techniques that guide students into accepting self-responsibility. Further, the student should be included whenever possible in the IEP planning meeting. This will empower the student and acknowledge his or her significance.

\section{Special Interests}

Determining how students' interests and talents can be used as motivators for them to learn curriculum content presents a real challenge for the IEP team and the special education teacher. Several team members brainstormed how best to use an adolescent youth's interest in catch-and-release fishing to motivate him to improve his classwork. None had any knowledge of the sport. Within a short time, however, they were able to generate a myriad of questions, to which they then assigned topics that could be included in the student's academic work in different subject areas.

Some of the questions and their corresponding applications in academic areas are as follows.

1. Physical skills. How is bait placed on the hook? How is the line thrown into the water and reeled in? How is the fish released without injury?

2. Science. How long can a fish be out of water before it dies? What are some species of fish? Can the catchand-release method be used with all types of fish? What weather conditions are conducive to fishing? What time of day is best for fishing?

3. Environmental studies. Why do people participate in catch-and-release fishing? Is this a popular sport? Compare the pros and cons of this kind of fishing to fishing for food.

4. Geography. How do fishermen learn about where to fish for specific species? What special clothing does a fisherman use in different geographical regions?

5. Mathematics. What are the costs for equipment, bait, clothing, license, and travel? How do these costs compare to those for freshwater or deep-sea fishing?

6. Literature. What reading material is available to someone interested in the sport? Who are the acknowledged experts? Would they make good models and mentors for someone new to the sport?

The team members admitted their enjoyment in generating the questions, adding that seeking input from colleagues facilitated the brainstorming and, in turn, added some zest to the IEP process. The next step was for the teacher to review the student's academic needs and insert the fishing topics as much as possible into his academic work.

\section{Students' Participation in the IEP Meeting}

Students can participate in education or transition planning meetings. Some students have learned The Self-Advocacy Strategy (Van Reusen, Bos, Schumaker, \& Deshler, 1994) before attending these meetings. The Strategy is prescribed in a manual that provides instruction for teaching students how to present themselves effectively at IEP meetings. The teacher (a) shares a rationale highlighting the value of the student attending the conferences, (b) obtains a commitment from the student to learn the strategy, and (c) models the behaviors for active student participation. The student engages in behavioral and verbal rehearsals of the skills, accompanied by the 
teacher's feedback, before participating in the actual meeting.

In acquiring the strategy, the students learn to take inventory of their strengths, recognize areas for improvement, and set goals. Mastery at each step results in their becoming able to conduct their own IEP meetings. They have been guided in cognitive learning, which empowers them to present themselves with an assessment of their strengths and weaknesses. They are prepared to ask and answer questions and to make suggestions. This approach to IEP sessions highlights the importance of the students' self-worth and demonstrates self-responsibility.

S. Probst (personal communication, April, 1996), a teacher of students identified with learning or behavior problems, devotes daily instruction using the self-advocacy strategy, often referred to as the "I" Plan, during the first 6 weeks of each school year. After that time, her intermediate-aged students conduct their own IEP conferences.

In 1996, 25 career teachers of troubled youth attended a workshop to learn the self-advocacy strategy. Probst described how she taught the strategy to her students and followed this with a videotape depicting one of her students conducting his own IEP review meeting. The career teachers were impressed with the boy's presentation and with what they themselves had learned in the workshop. As a result, they decided to teach the strategy to their students. Reports of their experiences reflected many successful meetings conducted by troubled youth.

The following comments are from the students and parents who attended the IEP meetings.

Students' comments: From a third-grade student: "It was the first time that I felt like people listened to me in a meeting. Usually, they just talked about me, but now I did a lot more of the talking and they listened." From a secondarylevel student: "It was great to have control over something .. . talking for myself . . . making some decisions."

Parents' comments: "I was so proud of him. I didn't know he [sixth-grade student] could do anything like that." "We were amazed. He [fourth-grade student] really showed a lot of maturity. It was great to listen to his plans for dealing with his problems. This meeting was very different because our son was talking about how he was going to work on his problems rather than denying he had any problems." "It is nice to see her [high school sophomore] take charge. She doesn't do that much at home."

One parent was upset about her son's role in decisions regarding goals: "I've always decided on goals for him until now!" Another parent commented to his son [fourth-grade student] in the meeting: "Did you make up these objectives by yourself? I can't believe you're doing this much talking about yourself. I'm proud of you. My boy is growing up!"

\section{Management and Intervention: Providing Positive Interactions}

Many management strategies available for use in the classroom are not based on punitive control systems described in the first part of the chapter! Benign confrontation and guidance of students into changing maladaptive behavior take time. Caring adults, those who believe in the dignity of youth, can create safe environments through the judicious selection and use of management techniques.

"Management" can refer to management of the physical environment, transition times, academic curriculum, students' schedules, teachers' time, students' maladaptive behavior, and so on. In this section management refers to intervention that involves self-management techniques designed to empower troubled youth to make responsible decisions that affect themselves and others.

\section{Cognitive Problem Solving}

Knowledge of problem-solving strategies empowers students. In its most positive sense, power means having choices. Giving students opportunities to make choices and recognize the outcomes of these choices is a current method for teaching students responsibility. Kaplan and Carter (1995) suggested that problem-solving skills are lifetime skills and that children need opportunities to think of their own solutions rather than always being told what to do. Among the many curriculum programs that include problem-solving strategies, most contain the key elements suggested by Spivack and Shure (1974) more than 20 years ago:

1. Recognize the problem.

2. Define the problem and the goal.

3. Generate alternative solutions.

4. Evaluate the solutions.

5. Design a plan.

One of these programs is SOCS, developed in 1972 by Roosa (personal communication), who continues to use it in his clinical practice. SOCS, an acronym for situation, options, consequences, and solution, has been adapted by social workers, special education, and general education teachers in a midwestern metropolitan area. Basically, the strategy encourages students to (a) discuss a problem situation, (b) share options for a solution, (c) describe all possible consequences for each option, and (d) select a solution from the identified options. When 
students share options and consequences, they learn different approaches to problems from each other. They are encouraged to consider many options, consequences, and solutions, and to evaluate the pros and cons of all. After a discussion, the students decide on a solution, which can be one of the identified options or a combination of options (see following box).

This approach to problem solving encourages students to think of alternatives and to think ahead to consequences of specific actions. The approach can lessen students' impulsivity because it expands their awareness of choices and encourages them to come up with alternatives and to think ahead to the consequences of their actions. For impulsive students and those who frequently engage in maladaptive responses or are limited to selecting the same response to problems, these are important concepts to assimilate.

Some teachers use the SOCS strategy regularly, often during periodically scheduled class meetings. They begin by introducing a series of problems that students can relate to but that do not include any emotionally charged issues. After the students become familiar with the SOCS process, problems in students' lives are used as the basis for discussions. Dialogue regarding private issues is shared between one student and the teacher.

In a general education middle-school class in which the students have become familiar and comfortable with the strategy, students do a paper-and-pencil version of SOCS. R. Winslow (personal communication, November, 1991) designed a form whereon the students write their responses to the following: (a) describe the problem situation, (b) list options, and (c) what will happen if I use this option?

After students have completed this section, the teacher recommends that they discuss the problem and possible options with others, and finally write down responses to (d) [Name] ..... thinks that ..... ; other items include ...... (e) This is what I will do to solve the problem; (f) Did you consider the consequences? (g) Would you like to role-play your chosen solution? (h) How did it go? These students apply the process to many of their situations, including selecting their course schedule. Students who use SOCS accept ownership for problem solving.

\section{Example of Application of SOCS Technique}

\section{Background:}

The assessment team evaluated Andrew at his neighborhood school when he was in the first grade. He was identified as "moderately mentally retarded" and placed in a special education program in another school building.

\section{Situation:}

Last winter Andrew, now a sixth-grade student, was reevaluated. The assessment team concluded that he was "learning disabled." Andrew was transferred to his home school in February and assigned to 4 hours of classes in general education and 2 hours in a special education resource room.

Andrew was extremely sensitive about his past school experiences. Teasing by his peers, who called him "retarded," "weirdo," and "mental," added to his sensitivity. He avoided peer interaction but worked diligently to keep pace with his classmates in the general education classes. He accomplished passing work with the help and support of his special education teacher.

\section{Problem:}

One morning Andrew entered the resource room with a problem. He had to give an oral book report in front of his literature class. He told his resource teacher that he "could not" and "would not" do it.

\section{SOCS problem-solving activity:}

The resource room teacher and Andrew sat down to solve the problem of his refusing to respond to an assignment that involved the oral report to the students in his literature class. Andrew identified the following options and consequences:

\section{Options}

1. Skip school.

2. Tell Mr. King [literature teacher] I lost my book.

3. Tell the teacher I lost the report.

4. Pretend I have laryngitis.

5. Tell Mr. King I won't do it.

6. Do it.

\section{Ask Mr. King if I can give the report to him after school.}

\section{Consequences}

I'll have to do it another day.

I'll have to read another book. The teacher will holler at me.

I'll get an "F."

I'll have to rewrite the report.

Mr. King might know l'm lying. The kids will laugh at me.

I'll still have to do it.

\section{He'll give me an "F."}

I'll mess up and make a fool of myself.

I'll be too nervous to talk. The kids will make fun of me.

He might say "no."

He might say "yes."

\section{Solution:}

After talking over the list of options and consequences with the resource teacher, Andrew chose to ask Mr. King if he could give the book report after school. Before he went to Mr. King, Andrew practiced giving the oral report to the resource teacher. This confirmed that he had read the book, had written the report, and could give the report orally. 
Next, Andrew and the resource teacher role-played the solution. First, Andrew took the part of Mr. King, and the teacher modeled several ways he could approach the teacher. Andrew chose the one that made him the most comfortable. Then the teacher assumed the role of Mr. King and Andrew rehearsed exactly what he would say until he felt confident.

Andrew approached Mr. King, who needed more convincing than Andrew had anticipated. He relented by saying, "Someday you'll have to do it in front of the group." Andrew gave the report after school and earned a "B" grade.

\section{Responsibility Contracts}

The responsibility contract is an example of a technique involving principles of behavior modification. The components of the contract remain constant, but the terms of the contract are highly individualized and can be used for an endless number of social and academic behaviors. The plan is designed to provide a positive, constructive course of action. It can help students understand that they have the responsibility and the ability to be self-directed.

Initially, a written contract is preferable to an oral contract because it allows the student and the teacher to maintain copies for reference at any time. For example, students who separate their behavior from its consequences or deny consequences can be referred to their contracts to remind themselves of their responsibilities.

Contract terms can be the responsibility of the student or the teacher, or can be shared by both. At first the teacher may have to assume leadership in determining the contract terms, thereby providing a model for subsequent contracts, which the students will assume fully. Through involvement in a series of contracts, students can learn to (a) set realistic goals, (b) decide on the values of attaining the goals, (c) determine steps to reach the goals, and (d) calculate the amount of time needed to attain the goals. When students accept these responsibilities, they begin to develop internal behavioral controls.

A responsibility contract should contain the following elements: (a) specific behavior to be learned (a criterion often is established); (b) specific goal (initially, reinforcers accompany goal attainment); (c) specific beginning time; (d) anticipated deadline date; (e) signatures of teacher and student; (f) date of signature; and $(\mathrm{g})$ written indication of contract completion.

The contract also includes a feedback section to engage students in self-evaluation. On the reverse side of the contract, spaces should be provided for the following: (a) Results of the agreement are ..... (b) Things that made this agreement easy to complete are ..... (c) Things that made this agreement hard to complete are ...... Briefly then, a contract could read as follows:

\begin{abstract}
I, Jason Smith, Jr., plan to work on one section of my science project each day for 15 minutes during study time. I will begin Monday, October, 1, and will finish by the assigned due date, October, 19 . When I reach this goal, it will be the first time I have turned something in on time. I also will have 15 minutes at the computer to work on the logo for our class T-shirts.
\end{abstract}

If the teacher had taken leadership when responsibility contracting was introduced, the students gradually assume full determination of the contract terms. The primary goal of the transition to student control is to provide opportunities for self-determination after students have experienced academic and social success. In short, before assuming full control of their contracts, students must gain some belief in their own ability, be capable of estimating the time required to complete the task, and be able to enjoy attaining the goals.

\section{Crisis Intervention}

Life space crisis interviewing (LSCI) is a verbal mediation strategy that engages students in dialogues to defuse and deescalate crises. These interviews are intended to relieve enraged feelings and invite student cooperation in solving problems with acceptable solutions. The interviews provide students with insights into their patterns of self-defeating behaviors. "It is a way of living with troubled and troubling students; understanding the dynamics of thought and feeling underlying behavior and the emotional interplay between the student and others in his life" (Long \& Fecser, 1996, p. 3). Crisis is viewed as a time for learning; however, the interview can be used in a variety of situations when students need mediation between themselves and life realities.

In the interview, the adult moves a student through these stages: (a) drain off the inflamed emotions, (b) discover what happened by listening and questioning carefully [let the student tell his or her story], (c) discover the central issue, (d) help students gain insight by connecting their feelings to behaviors, and (e) collaborate in selecting a solution that a student can use to avoid future self-defeating behaviors and improve future interactions.

For many years, proponents of this intervention strategy have emphasized the importance of the interviewer's personal qualities to ensure successful outcomes. These qualities are not confined to those who advocate LSCI; they are desirable for all teachers when using management techniques. The qualities include (a) warmth and concern for the student's 
feelings and problems; (b) an ability to maintain an ongoing relationship with the student; (c) an empathic relationship (the ability to see events from the student's point of view); (d) an ability to recognize psychological pain; (e) an ability to accept hostility, anger, and other agitating feelings without acting counteraggressively or defensively (Dembinski, 1981; Long \& Fagen, 1981; Morse, 1980; Wood \& Long, 1991).

SOCS, responsibility contracts, and life space crisis interviews are humanistic strategies that can be used effectively for talking with students, guiding them into accepting responsibility for their behaviors, and giving them options for behavioral changes. The adults using these approaches convey trust, care, and respect while at the same time expecting accountability.

All three strategies conclude with a solution behavior, which can be applied when similar problems, crises, or events occur in the future. Although students may respond favorably to any one of these strategies and verbalize a responsible solution, they may be unable to follow through with the plan because they do not know how to perform the new behavior. Therefore, we must ensure that students learn the new social skill and have opportunities to rehearse the skill in several contexts. Initially, these experiences can occur in a simulated setting, such as the safety of the classroom environment. Whenever possible, though, they should take place in the natural environment where a future conflict situation is likely to occur.

The following sequence illustrates the steps in teaching a new social skill:

1. Highlight the student's solution decision by emphasizing its benefits.

2. Model the behavior used in the solution.

3. Ask the student to describe what he or she saw in the modeling scene.

4. Allow time for positive practice.

5. Provide a scripted list of the essential behaviors required to carry out the solution, such as, "look directly at the adult"; say, "excuse me"; "use a pleasant voice tone."

6. Ask the students to recite the script verbally and commit it to memory.

The first five steps listed above help in overt responding, and the last step aids in covert behavior. Repetition of the script will help the student subvocalize it, thus internalizing the steps for applying the new behavior. To ensure effective results, the student will need this self-instruction when using the new behavior (Gallagher, 1988).

\section{Remarks: Communicating Thoughtful Statements}

Our professional responses to students are important. The school day is replete with opportunities to provide feedback, defined here as "knowledge of results." Most teachers feel at ease using positive feedback when students give correct answers or perform in the expected manner. When students' responses are incorrect, incomplete, or nonsensical, however, many teachers tend to use put-downs. Where did they get the idea that to make children improve, they must make them feel inferior first?

As exemplified in the first part of this chapter, children manage put-downs in one of several harmful ways such as (a) returning the attack, (b) "getting back" at a later time, or (c) remaining silent while experiencing feelings of unworthiness. Students who have been victims of put-downs and have a history of academic failure, interpersonal conflict, and unacceptable behavior need generous amounts of thoughtful and positive feedback. Encouraging feedback can motivate students and convey belief in their self-worth.

\section{Positive Feedback}

Sometimes students are motivated by recognition of even minuscule accomplishments and efforts until their pattern of success has replaced the old pattern of failures. Opinions of how often to use positive feedback vary. For example, Wilson (1986) recommended a ratio of six positive statements to each negative one; Sprick (1981) suggested that teachers can improve the quality of interactions with students by providing a three-to-one ratio of positive feedback versus negative comments in order to raise students' self-esteem level. Sprick defined negative feedback as statements and reminders that focus on something that needs correction or attention; for example, "Write the page number where you found the correct answers for all the items that have been circled in red"; "Don't forget to bring your permission slips for our Walk for Hunger."

Knowledge of results can be conveyed in a positive or a negative manner. For example, Malcom's desk usually looks like an archaeological dig; however, on his own initiative he cleaned and straightened it out. In response, a teacher's verbal feedback might be, "Oh, you finally straightened out your desk!" Or it might be, "Great, Malcom, you straightened out your desk. It looks so organized!" Obviously, the former remark is a put-down, whereas the latter provides recognition of his efforts.

For highly discouraged and insecure students, feedback should be positive, immediate, and frequent. In these cases, teachers go beyond the usual "good" and "very good" and in- 
stead use more interesting and individualized comments such as, "Alfonso, you were on top of this one"; "Danielle, you are really an Olympian when it comes to fractions"; "Tyler, thumbs up on your report."

In addition to verbal acknowledgments, feedback may be given in a visual format so students have something tangible they can keep and look over as often as they want. Teachers often use cleverly designed notes for younger students and charts and graphs for older students. Some students respond to positive feedback when it is exaggerated. For example, a student learning the spelling of new science words could record the number of correctly spelled words on $1 / 4^{\prime \prime}$ graph paper by plotting and connecting dots or plotting a cumulative recording. The latter graph results in an ascending progress line that may be more reinforcing than the plots on a standard graph.

Some teachers have highlighted progress in a creative and personal way. After many contact hours with Chip, a depressed student, a moment of pleasure occurred when he learned how to use the video camera. When Chip arrived in class the next day, he received a laminated credit card-size operator's license indicating that he was a capable camera man. This creative, tangible feedback delighted the student, who was observed looking at it frequently and showing it to several adults.

\section{Corrective Feedback}

Corrective feedback, not put-downs, should be used for students' incorrect responses. The following dialogue illustrates how a caring teacher managed Kim's incorrect answer and led Kim to a viable learning experience. Kim answered "yes" to the following question: "If your family leaves Kansas City at 6:00 a.m., can they arrive by car in Denver by 10:00 a.m. the same day?" When the teacher asked Kim to share how she arrived at "yes," Kim explained that "Denver doesn't look far from Kansas City on the map." Kim received corrective feedback that instructed her how to arrive at the correct answer and the skill needed to answer similar questions successfully in the future. The following is their dialogue.

“Kim, Denver doesn't look far from Kansas City when you look at a map as you did and 'eyeballed' the distance. Let's look at the map again and see if you can find lines with numbers written on or above them. Begin looking at lines near Kansas City. Yes, you found one. The number indicates the number of miles between Kansas City and the next city, Topeka. Okay. Continue following the lines going west on Interstate 70. Read the numbers, and I'll write them down in a column. ... Okay. You have reached Denver with your finger. Now here are the number of miles you found on the lines. Add up the miles . . 586 miles. That's correct.
"If your father drives 65 miles an hour, can you calculate how long it will take to drive 586 miles? Yes, you divide. You have it! It will take 9 hours if he makes no stops. Now you have learned how to calculate mileage using a map to give you information. If you get a chance to visit any city in the United States, which one would it be? ... San Francisco? Lets look at the map, and you 'eyeball' it. Is Denver or San Francisco farther from Kansas City? ... San Francisco? Right again. You can eyeball maps to get a general 'fix' on locations, but to know how long it would take to drive there, you would need to have specific information. Do you want to calculate how long it would take to drive there? ... "Okay, I'll be your record keeper as you locate the miles." This feedback session illustrated to Kim that her answers were valued and that an incorrect response is not failure but, instead, an opportunity to move forward.

Trying to understand a student's comment during the news-sharing period, a teacher, Mr. Rivers, stated, "I don't get what you are trying to say." This comment is too general and negative-sounding, making the student feel unimportant. Instead, the teacher should provide some support. For example: "Diego, we have been talking about violence, and you were talking about a man found on the steps of your neighbor's house. Was this man sleeping, injured, or dead? "In this instance, the teacher provides prompts to encourage the responsive student to continue telling his news and sharing with his peers.

\section{Dignifying Errors}

Hunter (as cited in Gentile, 1988) advocated the technique of dignifying errors in response to students' incorrect answers. According to Hunter, when a student gives a wrong answer, “there isn't just one thing the student doesn't know; there are two. One, the student doesn't know the correct answer to a question. Two, the student doesn't know the question to which the incorrect answer really belongs" (pp. 87-88). She recommended dignifying the student's response by supplying the question or statement to which the answer belonged, followed by giving the student some prompts to help him or her come up with the correct answer. Once this is accomplished, the student is held accountable for the information. Hunter believes that students who receive dignifying responses to incorrect answers participate more enthusiastically and venture more responses because they know the teacher will maintain their dignity.

Kim's teacher used Hunter's three recommendations. She accepted Kim's incorrect answer "yes" by telling her that it was a correct answer when she eyeballed the map. Then she 
gave Kim prompts and support in learning how to calculate map mileage. Last, she held Kim accountable by asking her to calculate mileage to another city, San Francisco.

\section{Student Input for Feedback}

Teachers can involve their students by asking how they would like to receive positive and corrective feedback. A fifth-grade class was asked, "When you have done a good job on a test or an assignment, or have done something nice for someone, how would you like the teacher to let you know?" The answers were: positive notes, phone calls to parents, pats on the back, positive comments on papers, stickers on our papers. The class then was asked, "If you have not done well on a test or an assignment, or if your behavior has been inappropriate, how do you want the teacher to let you know about it?" The students responded: Call me to your desk to look over the errors; hear first about the positive side before the errors are gone over; send notes home about academic problems but not for behavior problems.

All the students wanted the feedback to be given individually and confidentially. They did not want feedback in front of the group. Responses from kindergarten to secondary students have been informative to teachers who sought to determine what students wanted in the way of feedback. Many contained surprise elements, which were useful for teachers as they planned individual feedback. One sixth-grade student, for example, wanted a positive note placed in an interoffice envelope, which he could deliver to the principal.

\section{Behavior Descriptions: Fairness, Respect, and Support}

There is no way to avoid negatives. Many of us, however, tend to see what is wrong before we see what is right. This must change if we want to put an end to words and deeds that damage students. Wilson (1986) suggested that teachers make a sincere effort to assess their behaviors to learn whether they are "positive, negative, or neutral relative to the various conditions which exist in the classroom" (p. 4). On that basis, teachers then could develop a reservoir of positives to use to offset the negatives and achieve Wilson's recommended sixto-one ratio of positive versus negative feedback. Then teachers would be more likely to eliminate criticism, acknowledge students' abilities and efforts, and respond in caring ways.

\section{Encouraging Words}

The following illustrates how rephrasing the report of a student's work can emphasize her positive efforts. Shanna and her classmates had completed an academic task that required four steps, each with three trials. It was necessary to achieve $100 \%$ on a trial before the student could proceed to the next step. The following descriptions are both accurate, but one is clearly more positive and encouraging than the other:

Description 1: Shanna failed to achieve criterion on the first trial of Step 1 but succeeded with $100 \%$ on the second trial. She achieved criterion on the first trial of Step 2 but failed two trials before she mastered Step 3. She needed another trial to reach mastery on Step 4.

Description 2: Shanna was successful on trial two of Step 1. She reached $100 \%$ on that trial. She achieved $100 \%$ on the first trial in Step 2. After completing two trials in Step 3, she reached mastery and advanced to Step 4 . She reached mastery in Step 4 in one trial.

Clearly, the first description refers to failure and the second contains more positives and, therefore, is more likely to encourage the student's efforts in similar tasks. Students without a backlog of success have less tolerance for failure; therefore, frequent encouragement, is essential.

\section{Living with Mistakes and Failures}

Teachers need to instruct students in how to live with and manage mistakes and failures. Lessons can be introduced to help students view mistakes and failures as natural, sometimes valuable learning events in life. Teachers can begin by sharing their own mistakes and failures. For example: "I forgot to pierce the potatoes before I placed them in the microwave. They exploded and I had a real mess to clean up!"; "Inadvertently, I told someone that she was gaining weight, and she became upset." Ask students to relate their own mistakes, then provide a definition of "mistake," such as: "A mistake is anything you do, or didn't do, that later, upon reflection, you wish you had done differently" (McKay \& Fanning, 1987, p. 127). Teachers might suggest types of mistakes such as not planning ahead, rushing through tasks, making poor decisions, causing social blunders, or not taking advantage of an opportunity.

Once the students recognize that mistakes are inevitable and that mistakes have names, they can look at possible causes. These might be forgetting, denying, continuing a habit, or lacking knowledge about alternatives. When students acknowledge the types and causes of their mistakes, they can begin to think about how to avoid mistakes in the future. Students who engage in self-blame can shift self-inflicted reproaches of feeling bad, ignorant, stupid, or dumb to identifying the mistakes as ineffective or unwise. Then they can ask a question: "What can I do differently to make a better decision in the future?" (McKay \& Fanning, 1987). 
To understand that mistakes are natural, that some can be managed and others can be prevented, students can be given the instruction to ask someone they admire how he or she manages mistakes. Students also can read about the lives of successful people and discover how they manage their mistakes. Many students will enjoy reading the book, Mistakes that Worked (Jones, 1991), which contains descriptions of mistakes that became products, such as Frisbees, Coca-Cola, potato chips, aspirin, Post-it notes, and Velcro.

A teacher should begin the lessons on mistakes with examples that do not create an emotional upheaval. For example, Jim Flying Hawk, an excellent athlete, was not allowed to play on the basketball team because he would not cut his long hair. His outburst with the coach resulted in a 2-day school suspension. Soon after Jim's suspension, a lesson on how to avoid confrontations with school staff could involve strong emotions. When students feel comfortable with the knowledge that everyone makes mistakes and that the critical variable is what individuals do with them, students can learn new behaviors for future management of mistakes that have been injurious to themselves or others.

Teachers can guide students into understanding failure. A discussion can begin with the definition of failure as a performance that did not reach a goal with an expected level of success. Students can be helped to realize that "we all fail." Failure is an inevitable part of life. Nevertheless, most of us would rather highlight our successes because acknowledging our failures can be humiliating and frightening.

Students can be taught to view failure as a learning experience. They could become acquainted with the concept of successive approximations, or the incremental progression of steps to reach a goal. Have them think of the value in the statement, "Yard by yard, life is hard, but inch by inch makes it a cinch" (author unknown). Students can then share examples of their failed attempts to reach a goal and together, they can work out the incremental steps they might have used to reach that goal.

The teacher could select or develop additional activities highlighting the value of seeing failures as opportunities for growth. For example, older students could participate in a discussion about the statement, "Failure is a spectator sport. No matter what our personal views of failure may be, Americans like nothing better than a resounding flop. The bigger the better" (Gavin, 1987, p. 9). To keep students mindful that failure is inevitable, that some failures can be corrected and others cannot, teachers can borrow sayings that serve as reminders, such as "Failure is not falling down; it is staying down"; "Fail forward"; "Fail courageously"; "Success is neverending; fail- ure is never final; there is life after failure." Students can make posters illustrating these sayings and place them on their classroom's bulletin board or wall.

\section{PROMOTING DIGNITY THROUGH ALTRUISTIC EXPERIENCES}

Hope is an essential quality that students need for school success. Altruistic experiences can provide hope, which in turn can lead to optimism (Curwin, 1993). Brendtro, Brokenleg, and Van Bockern (1990) and Kohn (1991) believe that caring for and helping others can have a healing effect.

Children and youth identified as troubled, at-risk, or "on the edge" are among the last to have hope and to have opportunities to serve others. For these children, who have been characterized as feeling worthless, hopeless, and discouraged, "opportunities to help others may provide a way to break the devastating cycle of failure; substitute caring for anger and replace low self-esteem with feelings of worth. ... Altruism is an antidote to cynicism, encouraging those who 'couldn't care less' to begin to 'care more' " (Curwin, 1993 p. 65).

Brendtro et al. $(1990,1994)$ expressed concern about the conditions that have created at-risk students and about some of the interventions commonly used to change students' behavior. As an alternative, they developed a theory for reclaiming youth at risk, which concluded in a paradigm for rethinking our approaches to educating troubled youth. They combined developmental theory with their teaching and childcare experiences and selected existing intervention methods based on Native American philosophy into a paradigm called the Circle of Courage. The paradigm embraces four major values: generosity, belonging, independence, and mastery. These authors included generosity because of their concern that "without a spirit of generosity, children are inconsiderate of others, self-indulgent, and devoid of real purpose for living" (p. 8). By reaching out to help others, children may find worthiness in themselves.

Another powerful influence of Native American culture is the spirit of belonging, which centers on the belief that we are all related. Many Native American tribes believe that, to achieve a balanced life, we have to gain a balance in relationships between young and old members of the tribe, as well as with animals, plants, and all living things. Kohn (1991) voiced a similar belief regarding relationships, suggesting the importance of teachers' encouraging children to participate in caring for the community and internalizing the value of community. 
In some traditional, Native American cultures, mastery refers to personal mastery, the development of competence in social skills and scholarship. Children also were taught to celebrate others' achievements and to view them as models, not adversaries. They were given many opportunities to make decisions, solve problems, and accept responsibility, which in turn helped them grow independently. Children were taught to respect through inner discipline, not unwavering obedience.

Many of the authors cited in this chapter suggest that, in addition to independence and mastery, the values of belonging, community, relationships, caring, generosity, and altruism be included in the education of all children, including those identified as behavior disordered, troubled, at risk, or on the edge.

\section{Providing Caring Experiences}

The renewed interest in altruism is encouraging, as is the inclusion of troubled youth in current discussions and recommendations regarding caregiving. School children, ranging in age from young children to adolescents, have developed caring relationships with peers, older students, and adults in a variety of service activities reported by their teachers, as well as professional journals and newspapers. The activities, carried out during class time, lunch, study hall, recess, scheduled care time, after-school hours, and on weekends illustrate how altruism can become part of a student's life.

Teachers wishing to initiate a service program have to make advance preparations. The following suggestions by Curwin (1993) may be used to launch a program:

- Select opportunities that are genuine.

- Choose tasks that match the students' ability.

- Make opportunities optional.

- Do not praise the helper, especially in public. (The goal of helping is to give students an internal feeling of worth.)

- Provide a variety of possibilities.

- Provide enough time for positive results to occur.

- Make sure those being helped want to be helped.

- Set up reasonable expectations. (pp. 66-67)

Also, students need to be initiated to the concept of service and to receive advance preparation for their service work. One teacher began her program by reading the book Miss Rumphius (Cooney, 1982). The story reveals the life of Alice, whose beloved grandfather told her she must do one thing to make the world more beautiful. Alice does not know what that will be until she has grown old and is ill. Her service creates a beautiful environment for all in her community to enjoy.

Programs have been initiated by individual teachers, students, paraprofessionals, school nurses, and community members. Some students do activities within the school, and others work in the community. The following reported activities suggest a wide range of services that students have extended to others.

\section{Classroom Assistant}

Middle grade students have served as teacher assistants in kindergarten and primary grades. They have helped children put on and take off coats, jackets, boots, bookbags; tied shoes; provided encouragement as children engage in tasks; offered assistance during art activities.

\section{Library Assistant}

Students return books, audiotapes, and videotapes to library shelves and check items returned in the book drop. One autistic 12-year-old boy with a penchant for reading and an insistence for sameness did an excellent job returning books to the shelves and keeping all books aligned on the shelves. $\mathrm{He}$ also read once a week to a primary class of students with health impairments and physical disabilities. On several occasions he was observed giving gentle verbal reminders and touches to restless students.

\section{Save the Plants}

A special education paraprofessional collects plants that the local supermarket has scheduled for trash collection. Her class adopts the plants and learns how to nurture them back to health. The students give the surviving plants to various recipients, including nursing home residents, ill schoolmates, and school personnel on special occasions.

\section{Senior Assistant}

Adolescents in a residential facility in a small town do a variety of services for senior citizens, including changing light bulbs, washing windows, raking leaves, cleaning gutters, and shoveling snow. They also sponsor a senior dance each spring.

\section{Arbor Day Planting}

A class of students helped adult civic organization members with their Arbor Day event. Each citizen in the town can 
request one young tree that the civic organization has purchased and also can request help in planting the tree. The students worked side by side with the adults to do the planting.

\section{Placements for Conventioneers}

Primary-grade students made placemats for adults attending an educational conference in their city. The children drew pictures on $12^{\prime \prime}$ by $18^{\prime \prime}$ paper and added their names and a sentence about themselves. The teacher laminated the drawings, which became the placemats. The adults were delighted with their individualized drawings.

\section{Winter Blanket Drive}

Students planned a dance-a-thon, collecting pledges from family members, neighbors, and others who responded to their door-to-door campaign. They conducted the dance-a-thon over a weekend in the community center. With their pledge money, they bought winter blankets for a homeless shelter. They also accepted blankets and paid for the cleaning.

\section{Goodwill Ambassador}

Students select specific dates when they are available to the school secretary to escort visitors to various locations in the school. They also serve as "welcome buddies" for new students.

\section{Neighbor's Helper}

Young students help neighbors carry out the trash and bring newspapers to their doorsteps.

\section{Custodian Cadre}

A special education class volunteered to help a custodian who had suffered a back injury. Class members asked the custodian if he could use some "willing hands and backs." Although the custodian was hesitant to have the "troublemakers" help out, he did see some merit to the offer. His biggest need was to have the chairs in the cafeteria lifted onto the tables when he swept the floor and to place them on the floor before the first lunch group arrived. On the days when he washed the floor, he also needed someone to move the large floor washer. The cadre set up a duty roster and was faithful to its commitment. Although the injured custodian no longer requires the assistance, the activity is in its third year. The students have a special fondness for "old Joe" and do not want to relinquish their time with him.

\section{Volunteer Fair}

A local organization, SHARE (Students Helping in Areas Related to Education), involves student volunteers in the community. Recently, 700 high school students signed up for services including serving meals to the elderly, teaching tennis to inner-city kids, tutoring elementary students, taking pets to visit nursing homes, working in soup kitchens, and driving for Meals on Wheels. During a yearly fair, students encourage others to join in a volunteer activity using promotional posters.

One student was encouraging others to join a teen advisory council to work in the drug and alcohol abuse program. He credited the council's efforts with helping him get through a youth diversion program, a court-ordered opportunity for juvenile offenders to clear their records. He said, "They helped me, so now I'm giving back." Another high school in the same district was able to get 1,700 students to commit to 2,200 volunteer activities during the sixth year of its program coordinated by a school nurse, who has a support team of 55 students and 20 parents.

\section{Wings}

A partnership between a middle school and an aviary group developed a garden to attract hummingbirds and butterflies. The students worked during 45-minute shifts for months under the leadership of a landscaping organization. They measured and mapped out the plantings, selected soil, seeds, and plants, and calculated the cost of every supply. Teamwork, which involved problem solving and cooperation, was an essential ingredient in the students' success. The garden is now a colorful refuge for the school and community to enjoy. One student remarked, "I'm proud of the work we did. It's really a beautiful spot" (Peck, 1996).

\section{Letters for the Homebound}

A professional football player organized a group of eighth graders to participate in a national program that involves letter writing to residents who, because of age, disability, or illness, cannot leave their homes easily. The students begin their correspondence by addressing their letters, "Dear Friend," then relate something about themselves.

\section{Adopt a Wild Child}

Students in an elementary school raised money by selling environmental T-shirts. They donated the money they raised to the local zoo, which had promoted community care of its 
wildlife. Donated money was directed to the care of a specific animal, the donors' adoptee. The students in this school have been doing numerous environmental service projects, including selling cookies to help injured wildlife, collecting aluminum cans and telephone books for the recycling center, recycling toys for a day-care center, and collecting water samples in a nearby stream. These students also have bought, wrapped, and mailed packages of crayons, balloons, suckers, and hair ribbons to a school clinic in a Third-World country.

\section{Let Students Amaze Us}

Let the students amaze us by giving them opportunities to share and to learn for themselves that they are worthy. It is a significant way to promote dignity and eliminate the "demeaning D's."

Change in labels comes ... from genuine experiences. Those who are helped don't see the students as failures, so the labels become inappropriate. ... Changes in attitudes lead to hope-something that at-risk students desperately need. (Curwin, 1993, p. 68)

"To give without any reward, or any special notice, has a special quality of its own." - Anne Morrow Lindberg

\section{REFERENCES}

Brendtro, L. K., Brokenleg, M. \& Van Bockern, S. (1990). Reclaiming youth at risk. Bloomington, IN: National Education Service.

Brendtro, L. K. \& VanBockern, S. (1994). Courage for the discouraged: A psychological approach to troubled and troubling children. Focus on Exceptional Children, 26(8), 1-16.

Cooney, B. (1982). Miss Rumphius. Puffin Books/Penguin Books.

Curwin, R. L. (1993). The healing power of altruism. Educational Leadership, 51(3), 65-68.

Gavin, W. (1987). Flops, follies, and fiascoes: The great American preoccupation. Public Opinion, 7-10.

Gentile, J. R. (1988). Instructional improvement: A summary and analysis of Madeline Hunter's essential elements of instruction and supervision. Oxford, $\mathrm{OH}$ : National Staff Development Council.

Dembinski, R. J. (1981). The opening gambit: How students avoid the LSI. Pointer, 25(2), 5-8.

Gallagher, P. A. (1988). Teaching students with behavior disorders: Techniques and activities for classroom instruction. Denver: Love.

Haring, N. G., \& Phillips, E. L. (1962). Educating emotionally disturbed children. New York: McGraw Hill.
Johnson, D. W., \& Johnson, R. T. (1996). Peacemakers: Teaching students to resolve their own and schoolmates' conflicts. Focus on Exceptional Children, 28(6), 1-11.

Jones, C. F. (1991). Mistakes that work. New York: Bantam Doubleday Dell.

Kaplan, J. S., \& Carter, J. (1995). Beyond behavior modification: A cognitive-behavioral approach to behavior management in the school (3d. ed.). Austin, TX: Pro-Ed.

Kauffman, J. M., \& Pullen, P. L. (1996). Eight myths about special education. Focus on Exceptional Children, 28(5), 1-11.

Kindness is contagious . . . Catch it (1992). Merriam, KS: Stop Violence Coalition of Kansas City.

Knitzer, J., Steinberg, Z., \& Fleisch, B. (1990). At the schoolhouse door: An Examination of program and policies for children with behavioral and emotional behaviors. New York: Bank Street College of Education.

Kohn, A. (1991). Caring kids. The role of the schools. Phi Delta Kappan, 72(7), 497-506.

Lipsitz, J. (1995). Prologue. Why we should care about caring. Phi Delta Kappan, 76(9), 665-666.

Long, N. J., \& Fagen, S. (1981). Life space interviewing. Pointer, 25(2), 5-70.

Long, N. J., \& Fecser, F. A. (Producers). (1996). Life space crisis intervention (videos \& manual). Available from Institute of Psychoeducational Training, 226 Landis Road, Hagerston, MD 21740.

McGee, J. J., \& Menolascino, R. J. (1992). Gentle teaching: Its assumptions, methodology, and application. In W. Stainback \& S. Stainback (Eds.), Controversial issues confronting special education (pp. 183-200). Boston: Allyn \& Bacon.

McKay, M., \& Fanning, P. (1987). Self-esteem. Oakland, CA: New Habinger Publications.

Morse, W. C. (1980). Worksheet on life space interviewing for teachers. In N. J. Long, W. C. Morse, \& R. G. Newman (Eds.), Conflict in the classroom: The education of emotionally disturbed children (pp. 276-271). Belmont, CA: Wadsworth.

Morse, W. C. (1996). The role of caring in teaching children with behavior problems. In N. J. Long \& W. C. Morse (Eds.). Conflict in the classroom: The education of at risk and troubled students (pp. 106-112). Austin, Texas: Pro-Ed.

Neel, R. S., \& Cessna, K. K. (1993). Behavioral intent: Instructional content for students with behavior disorders. In K. K. Cessnas (Ed.), Instructionally differentiated programming: A needsbased approach for students with behavior disorders (pp. 31-39). Denver: Colorado Department of Education.

Nichols, P. (1992). The curriculum of control: Twelve reasons for it, some arguments against it. Beyond Behavior, 3(2), 5-11.

Noblit, G. W., Rogers, D. L., \& McCadden, B. M. (1995). In the meantime: The possibilities of caring. Phi Delta Kappan, 76(9), 680 .

Peacebuilders. (1995). Tucson: Heartsprings.

Peck, K. (1996). Testing their Wings. Birds and Blooms, 2(3), 32. 
Rogers, P. (1989). How can a student "fail" to be educated? Phi Delta Kappan, 70(6), 478-479.

Spivack, G., \& Shure, M. (1974). The problem-solving approach to adjustment. San Francisco: Jossey-Bass.

Sprick, R. (1981). Increasing positive interactions and improving the student's self-concept. In R. Sprick (Ed.), Solution book: A guide to classroom discipline (pp. 1-10). Chicago: Science Research Associates.
Van Reusen, A. K., Bos, C. S., Schumaker, J. B., \& Deshler, D. D. (1994). The self-advocacy strategy. Lawrence, KS: Edge Enterprises.

Wilson, A. (1986). The six-to-one ratio. The Master Teacher, 18(8), 1-3.

Wood, M. M., \& Long, N. J. (1991). Life space intervention: Talking with children and youth in crisis. Austin, TX: Pro-Ed.

\section{Professional update}

\section{INTERNATIONAL ASSOCIATION OF SPECIAL EDUCATION}

August 3-7, 1997

Cape Town, South Africa

Contact: Helmi Owens (206) 535-7292

School of Education

Pacific Lutheran University

Tacoma, WA 98447

\section{COUNCIL FOR LEARNING DISABILITIES}

October 23-25, 1997

Annual Conference

Hyatt Regency Crystal City

Arlington, Virginia

Contact: CLD

P.O. Box 40303

Overland Park, KS 66204

\section{PERMISSIONS AND COPYRIGHT}

All rights are reserved. No part of this publication may be reproduced, photocopied, faxed, stored in a retrieval system, or transmitted, in any form or by any means, electronic, mechanical, recording or otherwise, without the prior written permission of the publisher.
Back issues are available for sale. Reproduction requires permission and payment of fees. It is illegal and a violation of federal copyright law to reproduce this publication without permission. Direct all inquiries to the permissions editor. 


\section{Author Index}

Bean, Suzanne M. (September 1996)

Bergeron, Jeanne (April 1997)

Christensen, Linda (October 1996)

Cole, Cassandra McCory (February 1997)

Colucci, Karen (October 1996)

Dollard, Nolin (October 1996)

Egnor, David (October 1996)

Epanchin, Betty (October 1996)

Greenwood, Charles R. (January 1997)

Karnes, Frances A. (September 1996)

King-Sears, Margaret E. (March 1997)

Lago-Delello, Ellie (April 1997)

Lewis, Timothy J. (December 1996)

McLeskey, James (February 1997)

Mortweet, Susan L. (January 1997)

Montague, Marjorie (April 1997)

Sugai, George (December 1996)

Thorson, Sue (November 1996)

Utley, Cheryl A. (January 1997)

\section{INDEX • Volume 29}

\section{Chronological Index of Titles}

Leadership and the Gifted (September 1996)

Constructive Classroom Management

(October 1996)

The Missing Link: Students Discuss School

Discipline (November 1996)

Preferred and Promising Practices for Social

Skills Instruction (December 1996)

Peer-Mediated Instruction and Interventions

(January 1997)

Secondary Inclusion Programs for Students with Mild Disabilities (February 1997)

Best Academic Practices for Inclusive

Classrooms (March 1997)

Using Prevention Strategies in General

Education (April 1997)

Promoting Dignity: Taking the Destructive D's out of Behavior Disorders (May 1997) 